\title{
Feminististä pedagogiikkaa, opettaja!
}

Laukkanen, Anu, Miettinen, Sari, Elonheimo, Aino-Maija, Ojala, Hanna \& Saresma, Tuija (toim.) (2018). Feministisen pedagogiikan ABC - Opas ohjaajille ja opettajille. Vastapaino. 291 sivua.

AKTIIVINEN TASA-ARVOTYÖ ja koulun toimintakulttuurin kriittinen tarkastelu korostuvat Aikuisten perusopetuksen opetussuunnitelman perusteissa 2017. Asiakirja kuvaa koulun toimintakulttuuria sukupuolitietoiseksi ja tekee samalla pesäeroa aiempien opetussuunnitelmatekstien sukupuolineutraaliin perinteeseen.

Muutokset edellyttävät opettajilta tietoa sukupuoleen ja muihin erontekoihin kytkeytyvistä rakenteellisista kysymyksistä, mutta myös feministisen tutkimuksen virittämille toiminnallisille menetelmille on tilausta. Feministisen pedagogiikan $A B C$ vastaa tähän tarpeeseen, sillä se toimii tiedon lähteenä ja inspiraation jyvänä kasvatusalan tasaarvokysymysten haltuunotossa.

Yleistajuinen, feminististä pedagogiikka käsittelevä tietoteos valottaa koulutuskentän moninaisia tasa-arvokysymyksiä avaamalla ja syventämällä feministisen pedagogiikan perusteita ja historiaa. Se lähestyy teemoja asiantuntijoiden kokemusten ja toiminnallisten harjoitusten kautta.

Luin teosta aikuisopettajan silmin, koska feministisen pedagogiikan kysymykset ovat erityisen ajankohtaisia opettajille, joiden tehtävä on kehittää koulujen toimintakulttuuria nykyistä sukupuolitietoisemmaksi.

\section{TEOREETTISIA JÄSENNYKSIÄ} JA KOKEMUSTIETOA

Kirjan toimittajat ovat suomalaisen feministisen pedagogiikan asiantuntijoita, jotka sukupuolentutkimuksen yliopistoverkosto Hilma on koonnut yhteen. Teos antaa paljon tilaa yliopistokontekstille, mutta viitekehystä lavennetaan sen ulkopuolellekin. Kirjoittajat edustavat laajasti eri organisaatioita taiteen, koulutuksen, ohjauksen ja sukupuolentutkimuksen kentiltä, mikä rikastuttaa näkökulmien, kontekstien ja kysymystenasetteluiden kirjoa.

Teoksessa on neljä lukua. Ensin feminististä pedagogiikkaa lähestytään teoreettisesti, minkä jälkeen edetään pienin askelin kohti kokemustietoa ja menetelmiä. Aluksi pureudutaan feministisen pedagogiikan historiaan, feministisen teorian jäsennyksiin ja nykykeskustelun suuntaviivoihin. Otsikoissa vilisevät oikeutetusti sellaiset käsitteet kuin queer, intersektionaalisuus, luokkasensitiivisyys ja ableismi, mutta myös feministisen pedagogiikan suuri nimi bell hooks.

Avausluvussa feminististä pedagogiikkaa pitkään kehittänyt yliopistonlehtori Hanna Ojala esittelee käsitteellisiä ja teoreettisia jäsennystapoja, joilla on

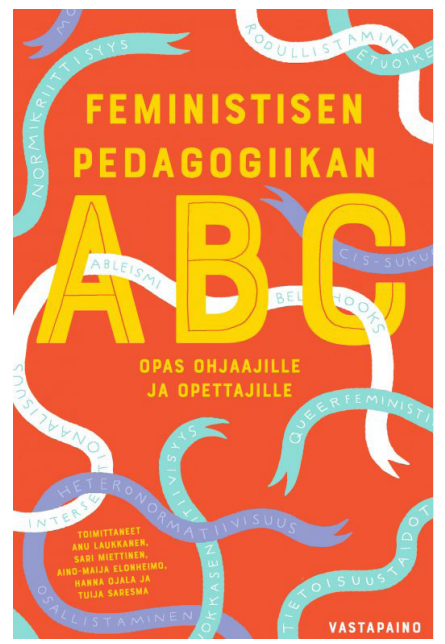

mahdollista hahmottaa perusopetuksen tasa-arvotyön monitasoisuutta.

Yliopistotutkija Tuija Saresma määrittelee intersektionaalisuuden eroiksi ja erojen risteymiksi, niihin kiinnittyviksi valtahierarkioiksi ja erojen keskinäisiksi suhteiksi sekä tarjoaa teorian rinnalle konkretiaa. Hän saa lukijan kuvittelemaan itsensä keskelle moninaista opiskelijajoukkoa ja pohtimaan omia käsityksiä eroista ja normatiivisista olemisen tavoista. Saresma problematisoi poikahuolipuheella ylläpidettyä yksinkertaistettua kuvaa sukupuolittuneista ongelmista ja rohkaisee opettajia kehittämään yhä inklusiivisempia ja turvallisempia oppimisympäristöjä.

\section{KRIITTISIÄ KYSYMYKSIÄ KOULUN KÄYTÄNNÖILLE}

Toinen luku avaa feministisen pedagogiikan lukemattomia ja yllättäviäkin viitekehyksiä, joiden 


\section{OPETTAJIEN ON MAHDOLLISTA}

\section{UUSINTAA TAI UUDISTAA}

VALTAJÄRJESTELMI ̈̈. kirjo ilmentää feministisen keskustelun laajuutta ja monitasoisuutta. Feminististä pedagogiikkaa sovelletaan teksteissä muun muassa kriminologian, talouden, turvapaikanhakuprosessin ja yliopisto-opetuksen viitekehyksissä. Luku on erityisen antoisa ohjaustyötä tekeville ja yliopistokentällä toimiville.

Luokanopettajaksi opiskeleva sarjakuvataiteilija Warda Ahmed sekä Ruskeat Tytöt -yhdistyksessä vaikuttava Helsingin yliopiston suunnittelija Mona Eid syventävät keskustelua intersektionaalisuudesta. He tarkastelevat kriittisesti uusimman perusopetuksen opetussuunnitelman perusteiden yhdenvertaisuutta, välittämistä ja turvallisuutta korostavia tavoitteita rodullistetun oppilaan näkökulmasta. Kokemustensa valossa he haastavat opetusalan toimijoita pohtimaan, millaisia käsityksiä normatiivisista ja marginaalisista oppilaana olemisen tavoista koulutuksen käytännöissä, opetusmateriaaleissa ja kielessä tuotetaan. Entä millaisia positioita tai toiminnan mahdollisuuksia oppilaille rakentuu vuorovaikutustilanteissa koulutuspolullaan?

Kolmas ja neljäs luku vievät teoriasta toimintaan. Lukijalle tarjotaan vinkkejä, menetelmiä ja valmiita materiaaleja, kuten vä- ritystehtäviä, opettajien ja ohjaajien käyttöön. Aikuisten perusopetuksen suunnitelman perusteissa sanotaan, että sukupuolten tasa-arvo on otettava huomioon erityisesti opetusmateriaaleja ja -menetelmiä valittaessa.

Luokanopettajia kouluttava yliopistonlehtori Jaana Pesonen kirjoittaa asiantuntevasti lastenkirjallisuuden kulttuurisia normeja vahvistavasta ja haastavasta voimasta. Hänen käsittelemänsä teokset ovat tuttuja lasten kanssa työskenteleville, mikä tekee feministisestä pedagogiikasta helposti lähestyttävää ja tuttavallista.

Pesonen osoittaa, kuinka opettajien on mahdollista uusintaa tai uudistaa valtajärjestelmiä muun muassa valitsemiensa oppimateriaalien kautta. Hän ohjaa opetusalan ammattilaisia kysymään kirjallisuudelta kriittisiä ja sukupuolittuneita valtarakenteita haastavia kysymyksiä.

\section{MONINAISUUS ON HEIKKOUS JA VAHVUUS}

Käsitteiden, näkökulmien ja viitekehysten moninaisuus on samalla kertaa teoksen heikkous ja vahvuus. Jos lukee kirjaa valikoiden, joutuu tekemään töitä tekstien viidakossa löytääkseen ne, jotka palvelevat omia tarpeita.
Eri taustoista tulevien feministisen pedagogiikan taitureiden saattaminen yhteen ja kokemustiedon arvottaminen korkealle taas niittävät kiitosta ja tarjoavat uusia tulokulmia feministiseen keskusteluun perehtyneellekin.

Erityisen tervetullutta on antaa ääntä niin feministisen keskustelun konkareille kuin kasvatusalan opiskelijoille ja kokemustiedolle. Perusopetuksen tasa-arvo- ja yhdenvertaisuustyöhön viittaaminen korostaa feministisen pedagogiikan kysymyksenasetteluiden ajankohtaisuutta ja tarpeellisuutta aikuisten perusopetuksessa. Koulutuksen tasa-arvotyöhön on kaivattu teoksen edustamaa moninäkökulmaista ja käytännön esimerkeillä havainnollistettua työkalupakkia, jota vasten opetushenkilökunta voi reflektoida omia kokemuksiaan ja käsityksiään.

\section{SALLA MYYRY}

KM, YTM, nuorempi tutkija Itä-Suomen yliopisto 